\title{
Evidence of altered structural and secretory glycoconjugates in the jejunal mucosa of patients with gluten sensitive enteropathy and subtotal villous atrophy
}

\author{
M VECCHI, G TORGANO, R DE FRANCHIS, S TRONCONI, D AGAPE, \\ AND G RONCHI
}

From the Istituto di Medicina Interna, Universita' di Milano, Milano, Italy

SUMmaRy The pattern of lectin histochemistry in formalin fixed, paraffin embedded normal jejunal and subtotal villous atrophy specimens from patients with gluten sensitive enteropathy were compared. There was no significant difference in the binding pattern of five lectins (Arachis hypogaea, Canavalia ensiformis, Lens culinaris, Phaseolus vulgaris and Triticum vulgaris) between normal and abnormal specimens. There were significant changes in the binding pattern of three lectins (Dolichos biflorus, Ulex europaeus, Ricinus communis), with special reference to goblet cells staining. These changes were present in all the specimens studied, regardless of the clinical diagnosis of dermatitis herpetiformis or coeliac disease. Dolichos biflorus reactive goblet cells were significantly decreased $(p<0 \cdot 001)$ in abnormal tissue and confined to the luminal edge of the mucosa. Strong reactivity of goblet cells in abnormal tissue was recorded with Ricinus communis and Ulex europaeus, lectins that bind to few or no goblet cells in normal tissue. These findings show that modifications of structural and secretory glycoconjugates occur in the jejunal mucosa of patients with gluten sensitive enteropathy.

Based on the selective binding of lectins to specific carbohydrate residues, lectin histochemistry has been widely used in the study of structural and secretory glycoconjugates in different tissues. ${ }^{1-4}$ As far as the gastrointestinal tract is concerned, the lectin binding pattern of normal colonic mucosa has been defined and changes of the normal pattern have been observed to occur in the course of neoplastic transformation as well as chronic inflammatory bowel disease. ${ }^{-4 x}$

We recently described the distribution of structural and secretory glycoconjugates in normal human jejunal mucosa, defining the specific binding pattern of eight lectins."

In the course of gluten sensitive enteropathy (GSE), jejunal mucosa undergoes severe changes, with flattening of villi, crypt hyperplasia and an increase in the epithelial mitotic index. ${ }^{\prime \prime-11}$ These

\footnotetext{
Address for correspondence: Maurizio Vecchi, MD, Istituto di Medicina Interna, Via Pace, 9-20122 Milano, Italy.

Accepted for publication 1 November 1988.
}

changes are believed to result from the earlier epithelial cell death induced by gluten and the consequent hyperplastic response of proliferative compartments occurring in GSE. Because of the increased cellular turnover, significant changes in the cell maturation cycle occur, resulting in the presence of morphologically and functionally immature enterocytes up to the luminal edge of the mucosa. ${ }^{12}$

The mechanism by which gluten induces these changes is unknown and many theories have been proposed. ${ }^{13-15}$ According to one of these theories, gluten or a fraction thereof, would bind to enterocytes through abnormal, exposed cell glycoproteins and act as a toxic lectin inducing cell toxicity by altering cell function. ${ }^{16}$ This theory postulates the presence, in jejunal mucosa of patients with GSE, of incomplete or altered glycoprotein receptors that would be available for the binding with gluten. ${ }^{17}$

In this paper, we studied the pattern of lectin histochemistry in the jejunal mucosa of patients with GSE in order to evaluate (1) the changes in the 
pattern of jejunal glycoconjugates and (2) the presence of abnormal carbohydrate receptors eventually associated with GSE.

\section{Methods}

JEJUNAL SPECIMENS

Fourteen jejunal biopsies performed in four patients with coeliac disease and 10 patients with dermatitis herpetiformis were studied. Dermatitis herpetiformis is a chronic, blistering skin disease constantly associated with jejunal lesions indistinguishable from those observed in coeliac disease. ${ }^{18-19}$ The diagnosis of dermatitis herpetiformis was based on the presence of typical granular $\operatorname{IgA}$ deposits at the dermal-epidermal junction as detected by immunofluorescence performed on perilesional skin. ${ }^{18}$ The diagnosis of coeliac disease was later confirmed in all four patients according to standardised criteria. ${ }^{20}$ All patients were on unrestricted diet at the time of biopsy and all the biopsies showed histological features of subtotal villous atrophy.

Ten jejunal biopsies showing normal morphology served as controls. These biopsies had been obtained as part of the clinical management of 10 patients undergoing evaluation for chronic diarrhoea or abdominal pain. The final diagnosis in all 10 subjects was irritable bowel syndrome.

As formalin fixation and paraffin embedding do not affect the binding of biotinylated lectins to jejunal sections, ${ }^{4}$ all samples were fixed in $10 \%$ formalin, embedded in paraffin and used for routine histology and lectin histochemistry.

LECTINS

The sugar specificities of each lectin studied are summarised in Table 1. Biotinylated conjugates of

Table 1 Lectins studied and sugar specificities

\begin{tabular}{|c|c|c|}
\hline Lectins & Carbohydrate specificity & Inhibitor \\
\hline $\begin{array}{l}\text { Arachis hypogaea } \\
\text { (PNA) }\end{array}$ & $\begin{array}{l}\text { Galactosyl- } \beta-(1-3)-N- \\
\text { Acetyl-D-galactosamine }\end{array}$ & D-Galactose \\
\hline $\begin{array}{l}\text { Ricinus communis } \\
\quad \text { (RCA) }\end{array}$ & D-Galactose & D-Galactose \\
\hline $\begin{array}{l}\text { Canavalia ensiformis } \\
\text { (ConA) }\end{array}$ & D-Glucose, D-Mannose & $\begin{array}{l}\text { D-Glucose, D- } \\
\text { Mannose }\end{array}$ \\
\hline $\begin{array}{l}\text { Lens culinaris } \\
\quad \text { (LCA) }\end{array}$ & D-Mannose, D-Glucose & $\begin{array}{l}\text { D-Mannose, D- } \\
\text { Glucose }\end{array}$ \\
\hline $\begin{array}{l}\text { Phaseolus vulgaris } \\
\text { (PHA) }\end{array}$ & $\begin{array}{l}\text { N-Acetyl-D- } \\
\text { Galactosamine }\end{array}$ & $\begin{array}{l}\text { N-Acetyl-D- } \\
\text { Galactosamine }\end{array}$ \\
\hline $\begin{array}{l}\text { Triticum vulgaris } \\
\text { (WGA) }\end{array}$ & $\begin{array}{l}\text { N-Acetyl-D-Glucosamine } \\
\text { N-Acetyl-neuraminic } \\
\text { acid }\end{array}$ & $\begin{array}{l}\text { N-Acetyl-D- } \\
\text { Glucosamine }\end{array}$ \\
\hline $\begin{array}{l}\text { Ulex europaeus } \\
\text { (UEA) }\end{array}$ & L-Fucose & L-Fucose \\
\hline $\begin{array}{l}\text { Dolichos biflorus } \\
\text { (DBA) }\end{array}$ & $\begin{array}{l}\alpha-N-A c e t y l-D- \\
\text { Galactosamine }\end{array}$ & $\begin{array}{l}\alpha-N-A c e t y l-D- \\
\text { Galactosamine }\end{array}$ \\
\hline
\end{tabular}

Arachis hypogaea (PNA), Ricinus communis (RCA), Canavalia ensiformis (ConA), Lens culinaris (LCA), Phaseolus vulgaris (PHA), Triticum vulgaris (WGA), Ulex europaeus (UEA), and Dolichos biflorus (DBA) were obtained from Vector Laboratories.

Preliminary experiments were carried out in order to determine the optimal working dilution for each lectin." According to these experiments, the optimal dilutions in phosphate buffered saline $0 \cdot 1 \mathrm{M}, \mathrm{pH} 7 \cdot 2$ for each lectin were as follows: PNA $12.5 \mu \mathrm{g} / \mathrm{ml}$; RCA $50 \mu \mathrm{g} / \mathrm{ml}$; ConA $16 \mu \mathrm{g} / \mathrm{ml}$; LCA $16 \mu \mathrm{g} /$ $\mathrm{ml}$; PHA $12.5 \mu \mathrm{g} / \mathrm{ml}$; WGA $6 \mu \mathrm{g} / \mathrm{ml}$; UEA 25 $\mu \mathrm{g} / \mathrm{ml} ;$ DBA $20 \mu \mathrm{g} / \mathrm{ml}$.

LECTIN HISTOCHEMISTRY

From each jejunal sample, four consecutive sections were cut for each lectin studied. For each lectin, two sections were incubated with the biotinylated lectin, one with the biotinylated lectin and the respective sugar inhibitor and one with PBS only.

Five micron thick sections from paraffin embedded specimens were deparaffinised and rehydrated in decreasing alcohols. An incubation in PBS containing $0.3 \% \mathrm{H}_{2} \mathrm{O}_{2}$ for 15 minutes was performed in order to block the endogenous peroxidase activity. Sections were then incubated with the specific biotinylated lectin for 30 minutes, with Avidin-BiotinPeroxidase complex (ABC kit, Vector Laboratories) for 30 minutes and with 3-amino-9-ethylcarbazole 0.5 $\mathrm{mg} / \mathrm{ml}$ in $0.2 \mathrm{M}$ sodium acetate buffer, $\mathrm{pH} 5.2$ containing $1 \% \mathrm{~N}-\mathrm{N}$ dimethyl formamide and $0.015 \%$ $\mathrm{H}_{2} \mathrm{O}_{2}$ for 10 minutes. Each incubation was performed at room temperature in a moist chamber. Between incubations, sections were washed twice in PBS at room temperature.

EVALUATION OF LECTIN LABELLING

The slides were observed under a Zeiss microscope for evaluation of lectin labelling, which was performed by two independent observers using a subjective score from 0 (no reactivity) to +++ (maximal reactivity). The scores reported in the results represent the mean score of the two observation for each lectin and each clinical situation.

The number of goblet cells reactive with DBA was evaluated by two independent observers. The count was obtained by evaluating five microscopic fields (original magnification $64 \times$ ) for each specimen. The number of goblet cells present in each field slightly differed between normal $($ mean $=67.5)$ and diseased specimens $($ mean $=43 \cdot 2)$ with no statistical difference. A total number of around 3.000 goblet cells were assessed for each clinical situation. In order to evaluate separately the percentage of reactive goblet cells in the crypts and the villi of subtotal villous 
Table 2 Patterns of reactivity of PNA, ConA, LCA, PHA, $W G A$ in normal specimens and in jejunal specimens with subtotal villous atrophy

\begin{tabular}{|c|c|c|c|c|c|}
\hline & $P N A$ & $\operatorname{Con} A$ & $L C A$ & $P H A$ & $W G A$ \\
\hline \multicolumn{6}{|l|}{ Villus goblet cells } \\
\hline Upper third & 0 & 0 & 0 & ++ & ++ \\
\hline Middle third & 0) & 0) & 0 & ++ & ++ \\
\hline Lower third & 0 & 0 & 0 & ++ & 0 \\
\hline \multicolumn{6}{|l|}{ Crypt goblet cells } \\
\hline $\begin{array}{l}\text { Superficial crypts } \\
\text { Lower crypts }\end{array}$ & 0 & 0 & 0 & $\begin{array}{l}++ \\
++\end{array}$ & $\begin{array}{l}0 \\
0\end{array}$ \\
\hline Lower crypts & 0 & 0 & 0 & ++ & \\
\hline Villus enterocytes & () & ++ & ++ & ++ & ++ \\
\hline Crypt enterocytes & 0 & ++ & + & ++ & + \\
\hline Lamina propria & 0 & ++ & + & ++ & ++ \\
\hline
\end{tabular}

0=no reactivity; $+=$ weak reactivity: $++=$ moderate reactivity:

$+++=$ intense reactivity.

atrophy specimens, we arbitrarily decided to consider as 'villus goblet cells' only those lining the intestinal lumen.

\section{Results}

The scores assigned by the two observers never differed by more than one degree of reactivity.

The pattern of lectin labelling observed in the jejunum of control subjects and patients with GSE is described in Tables 2 and 3. Five of the eight lectins studied (PNA, ConA, LCA, PHA, WGA) did not
Table 3 Patterns of reactivity of $D B A, U E A$, and $R C A$ in normal jejunal specimens $(N J)$ and jejunal specimens with subtotal villous atrophy (SVA)

\begin{tabular}{|c|c|c|c|c|c|c|}
\hline & \multicolumn{2}{|l|}{$D B A$} & \multicolumn{2}{|c|}{$U E A$} & \multicolumn{2}{|l|}{$R C A$} \\
\hline & $N J$ & $S V A$ & $N J$ & $S V A$ & $N J$ & $S V A$ \\
\hline Villus goblet cells & +++ & $+* / 0$ & ++ & ++ & 0 & ++ \\
\hline Crypt goblet cells & 0 & 0 & 0 & ++ & 0 & ++ \\
\hline Villus enterocytes & $++\dagger$ & $++\dagger$ & $+\dagger$ & $+\dagger$ & $+\ddagger / 0$ & $+\ddagger / 0$ \\
\hline Crypt enterocytes & $++t$ & $++\dagger$ & $+\dagger$ & $+\dagger$ & 0 & 0 \\
\hline Lamina propria & 0 & 0 & & ssels & + & + \\
\hline
\end{tabular}

$0=$ no reactivity; $+=$ weak reactivity; $++=$ moderate reactivity: $+++=$ intense reactivity. ${ }^{*}$ Reactivity of few goblet cells at the luminal side of the mucosa: †Labelling of the surface membrane: $\ddagger$ Labelling of the apical portion of the cytoplasm.

show any significant difference in labelling between normal specimens and specimens from patients with GSE and total villous atrophy (Table 2) and will not be described further. On the contrary, significant changes in the binding pattern of three lectins (DBA, UEA, RCA) were observed in specimens from patients with GSE, irrespectively of the diagnosis of dermatitis herpetiformis or coeliac disease (Table 3).

\section{DOLICHOS BIFLORUS}

Normal specimens (Fig. 1A)

Dolichos biflorus faintly stained the cytoplasm of enterocytes in normal jejunal specimens. The luminal side of enterocityc membrane was strongly

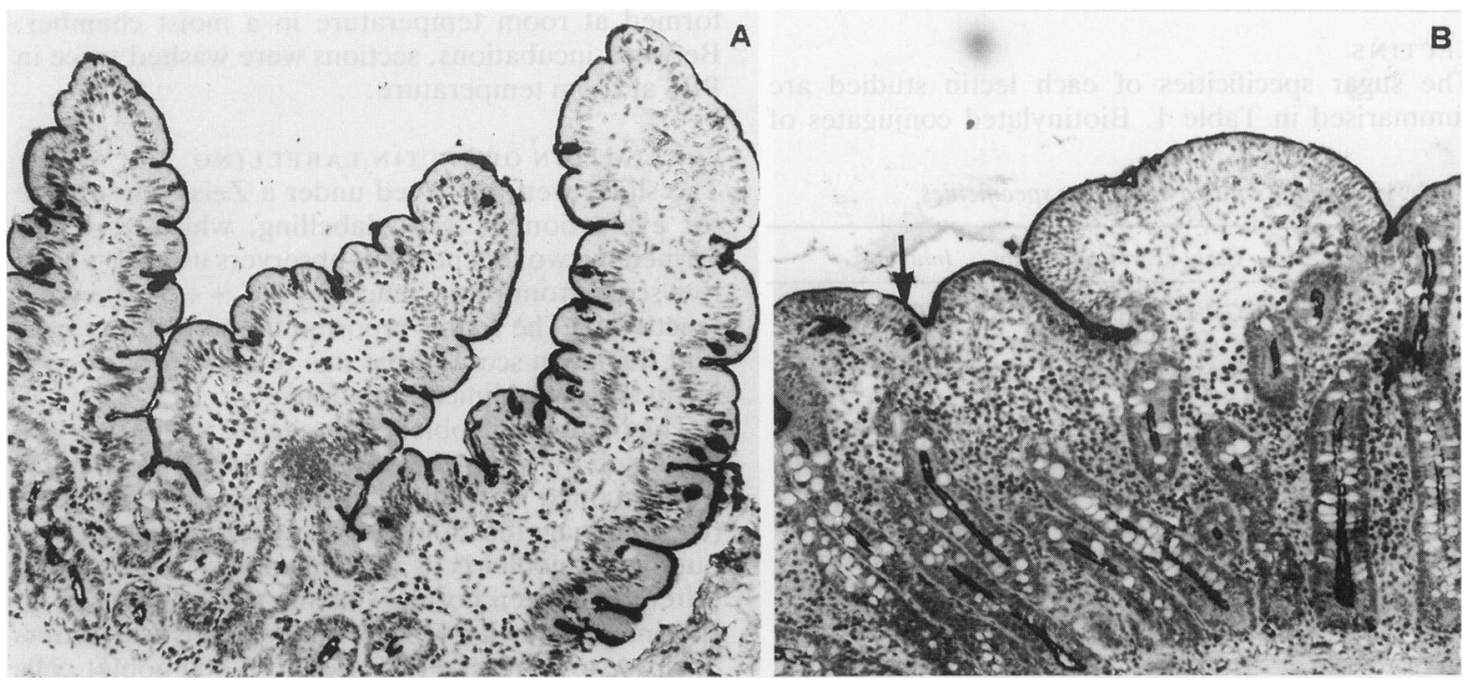

Fig. 1 (A) Normal jejunal mucosa, DBA histochemistry. DBA reactivity is localised to the luminal membrane of enterocytes and to goblet cells located in the upper two-thirds of the villi. (B) Jejunal mucosa with subtotal villous atrophy, DBA histochemistry. DBA reactivity is present at the luminal membrane of enterocytes and in very few goblet cells at the most luminal edge of the mucosa (arrow). 

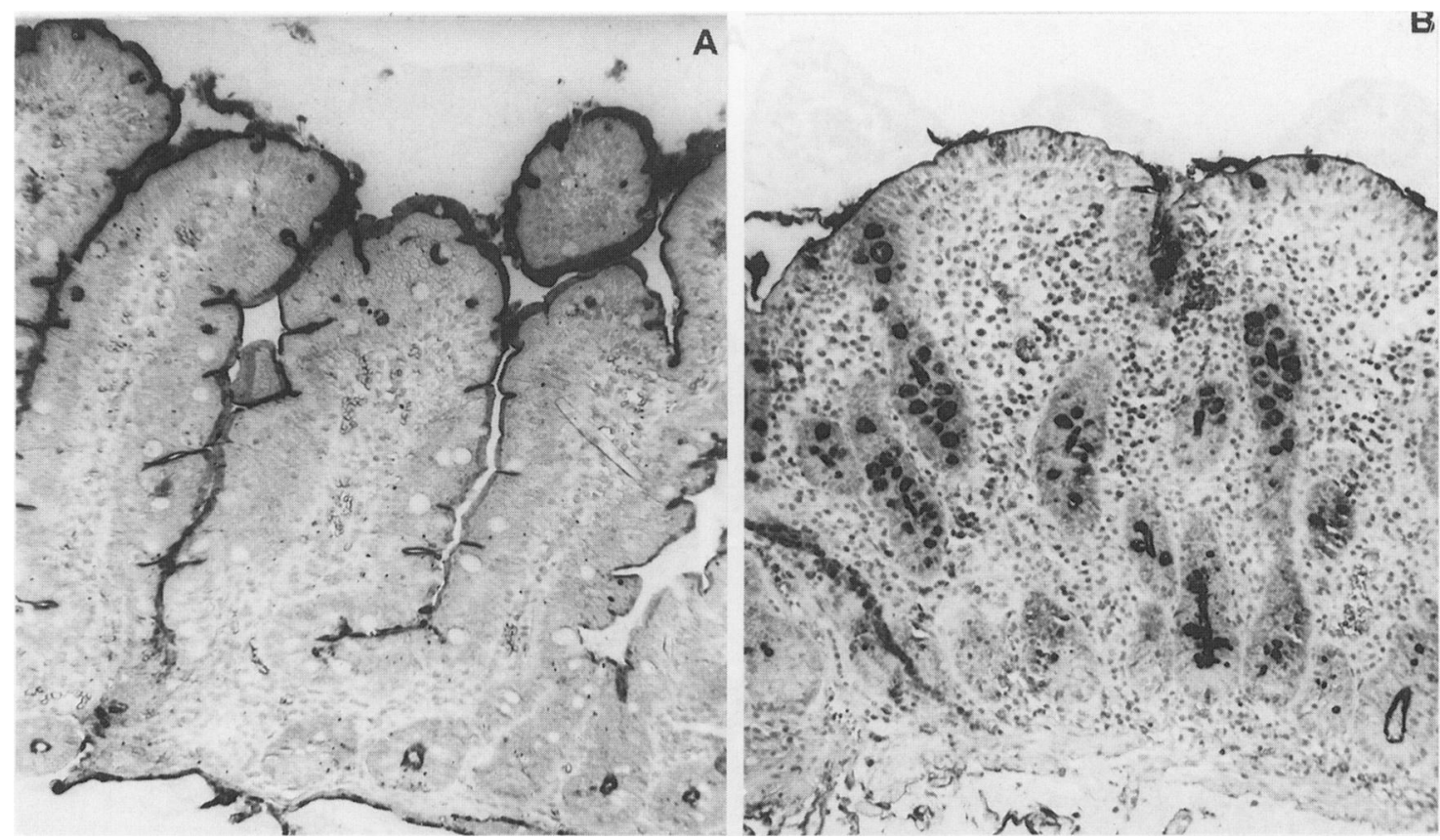

Fig. 2 (A) Normal jejunal mucosa, UEA histochemistry. UEA reactivity on the luminal membrane of enterocytes, few goblet cells in the upper portion of the villi and endothelial cells. (B) Jejunal mucosa with subtotal villous atrophy, UEA histochemistry. A strong reactivity is seen in all goblet cells; reactivity on the luminal membrane of enterocytes is also observed.

reactive, especially along the villi. Fifty five per cent of the goblet cells reacted with DBA in normal jejunum with marked differences in the binding according to the location of goblet cells in the cryptvillus axis: $84 \%$ of villus goblet cells (mainly located in the upper two thirds of the villi) reacted with DBA, whereas only $1 \%$ of crypt goblet cells did $(\mathrm{p}<0 \cdot 001)$.

Specimens with subtotal villous atrophy (Fig. 1B)

As far as enterocytes reactivity is concerned, DBA showed a binding pattern similar to that seen in normal specimens with a faint staining of the cytoplasm and a strong reactivity of the plasma membrane. On the contrary, a marked reduction in the number of DBA reactive goblet cells $(19 \%)$ was observed in subtotal villous atrophy as compared with normal specimens $(p<0.001)$. Fifty one per cent of villus goblet cells were reactive with DBA ( $<<0.001 v$ normal specimens). No differences were observed in the labelling of crypt goblet cells as compared to control specimens.

\section{ULEX EUROPAEUS}

\section{Normal specimens (Fig. 2A)}

In normal specimens, UEA reactivity was confined to enterocyte membranes and to a small percentage of goblet cells located in the upper portion of the villi. Endothelial cells in the lamina propria also reacted with UEA.

Specimens with subtotal villous atrophy (Fig. 2B)

Enterocyte reactivity in specimens with subtotal villous atrophy was similar to that observed in normal specimens. On the contrary, a strong reactivity of all goblet cells, regardless of their location on the cryptvillus axis, was observed.

\section{RICINUS COMMUNIS}

Normal specimens (Fig. 3A)

In normal sections, RCA showed some reactivity in the cytoplasm of enterocytes and in the lamina propria. No reactivity was observed in the goblet cells, whether located in the crypts or along the villi.

\section{Specimens with subtotal villous atrophy (Fig. 3B)}

In specimens with subtotal villous atrophy, RCA reacted with lamina propria cells and enterocytes in a way similar to that observed in normal jejunal specimens. On the contrary, a strong reactivity of goblet cells was consistently observed in all specimens with subtotal villous atrophy. 


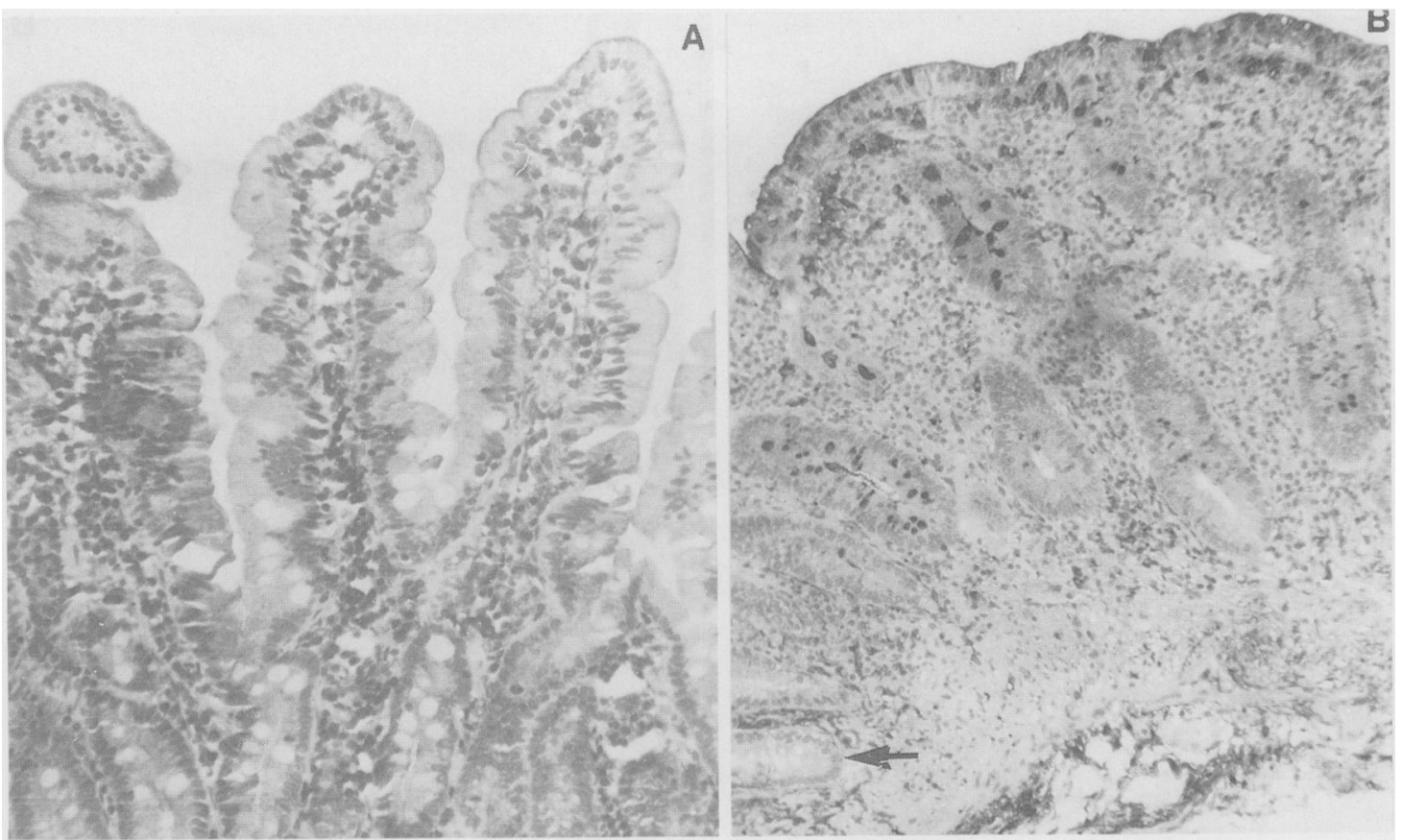

Fig. 3 (A) Normal jejunal mucosa, RCA histochemistry. A very faint reactivity of enterocyte cytoplasm is observed. (B) Jejunal mucosa with subtotal villous atrophy, RCA histochemistry. A small group of unreactive goblet cells is also observed (arrow).

\section{Discussion}

Significant changes in the binding pattern of three lectins were observed between normal jejunal specimens and jejunal specimens from patients with gluten sensitive enteropathy showing subtotal villous atrophy.

A statistically significant reduction in the total number of goblet cells reactive with DBA was observed in jejunal specimens with subtotal villous atrophy as compared with normal specimens $(19 \% v$ $55 \%, \mathrm{p}<0 \cdot(001)$. This difference was also significant when only villus goblet cells were considered $(51 \%$ and $84 \%$ in diseased and normal specimens respectively; $p<0 \cdot(001)$. In jejunal specimens with subtotal villous atrophy, DBA reactivity was confined to goblet cells located at the most luminal side of the mucosa.

On the contrary, UEA and RCA, lectins that react in normal specimens with a small number of goblet cells (UEA) or with no goblet cells at all (RCA), did show a strong reactivity with almost all goblet cells in specimens with SVA. The presence of the reactivity was not related to the location of goblet cells in the crypt-villus axis.

These changes seem to be strictly associated with GSE jejunal specimens with subtotal villous atrophy, because they were consistently observed in all 14 GSE specimens independently from the diagnosis of coeliac disease or dermatitis herpetiformis and were not seen in 10 normal jejunal specimens. These findings indicate that changes in the metabolism of structural and secretory glycoproteins occur in the course of GSE.

Glycoprotein synthesis takes place in the Golgi apparatus, where various carbohydrate residues are assembled to the original protein core in a posttranslational step. ${ }^{21}$ The addition and rearrangement of the various carbohydrate side chains is performed by different glycosyltransferase enzymes, "2 whose activity has been shown to be strictly related to the degree of cell differentiation. ${ }^{324}$ In normal human jejunum, epithelial cell life span has been proved to be approximately four days. ${ }^{25 n}$ In patients with GSE, an earlier epithelial cell death and a consequent increased epithelial cell turnover are induced by gluten. ${ }^{27}$ These changes in turn result in an incomplete cell maturation that is reflected by morphological, biochemical and functional changes.'

As cell maturation is incomplete in GSE patients, a reduction in the activity of glycosyltransferase enzymes could account for an incomplete glycoprotein synthesis and then for the changes in the glycoconjugate pattern observed by lectin histo- 
chemistry as for example the reduced binding of DBA to goblet cells. The fact that a complete differentiation is needed for goblet cells to show reactivity with DBA has also been observed in human colon, where DBA reactivity is considered to be a specific marker of mature goblet cells. ${ }^{67}$

In specimens with subtotal villous atrophy, the reduction of glycosyltransferase activity normally resulting in DBA reactivity might in turn lead to the availability of glycoprotein receptors for the binding to RCA or UEA, usually absent or not available in normal jejunum.

A second hypothesis should also be taken into account, however, in order to explain the changes observed in the lectin binding pattern. According to the 'lectin theory', dietary gluten would act, in patients with GSE, as a toxic lectin through the binding of exposed, altered carbohydrate residues. ${ }^{1617}$ In this respect, recent in vitro binding studies have shown that guten may contain carbohydrate residues with 'WGA-like activity' ${ }^{2 \times 29}$ that preferentially bind to GSE derived enterocytes as compared to normal enterocytes.

In our series, no difference in the binding of WGA to diseased and control specimens was detected by lectin histochemistry. On the contrary, RCA and UEA consistently reacted to goblet cells in GSE specimens but not to normal goblet cells. Although these reactivities have not been previously observed in in vitro binding studies, these findings strongly suggest the availability, in diseased specimens, of carbohydrate residues that are not present or available in normal jejunum.

In summary, the alterations of jejunal lectin binding pattern observed in GSE specimens could be secondary to the changes occurring in jejunal epithelial cells maturation; alternatively, they could actually identify a putative receptor available for gluten binding and toxic action as a primary defect of glycoconjugate metabolism.

The study of lectin binding pattern in the jejunum of patients with GSE on a gluten free diet and with normal jejunal histology will be critical in the evaluation of these hypotheses.

The authors are grateful to Dr Eliana Arosio and Miss Mariuccia Balestrieri for their skillful technical assistance. Parts of this work were published in abstract form in Gastroenterology 1985; 88: 1624.

\section{References}

1 Sharon N, Lis M. Lectins: cell-agglutinating and sugar specific protcins. Science 1972; 177: 949-59.

2 Brown JC, Hunt RC. Lectins. Int Rev Cytol 1978; 52: 277-349.

3 Zieske JD, Bernstein IA. Epidermal fucosylation of cell surface glycoproteins. Biochem Biophys Res Commun 1984: 119: 1028-33.

4 Sieber-Blum M, Cohen AM. Lectin binding to neural crest cells. Changes of the cell surface during differentiation in vitro. J Cell Biol 1978; 76: 628-38.

5 Gorelick FS, Sarras MP, Jamieson JD. Regional differences in lectin binding to colonic epithelium by fluorescent and electron microscopy. J Histochem Cytochem 1982; 30: 1097-1108.

6 Fisher J, Klcim PJ, Vierbuchen M, Skutta B, Uhlenbruck G, Fisher R. Histochemical distribution of lectins binding sites in normal alimentary tract as well as in benign and malignant gastric neoplasms. $J$ Histochem Cytochem 1984; 32: 681-9.

7 Boland CR, Montgomery CK, Kim JS. Alterations in human colonic mucus occurring with cellular differentiation and malignant transformation. Proc Natl Acad Sci USA 1982; 79: 2051-5.

8 Jacobs LR, Huber WP. Regional distribution and alterations of lectin binding to colorectal mucins in mucosal biopsies from controls and subjects with inflammatory bowel diseasc. J Clin Invest 1985 ; 75: 112-8.

9 Vecchi M. Torgano G, Monti M, et al. Evaluation of structural and secretory glycoconjugates in normal human jejunum by means of lectin histochemistry. Histochemistry 1987; 86: 359-64.

10 Rubin CE, Brandborg LL, Phelps PC, et al. Studies of celiac disease. I. The apparent identical and specific nature of the duodenal and proximal jejunal lesion in celiac disease and idiopathic sprue. Gastroenterology 1960; 38: 28-49.

11 Yardley JH, Bayless TM, Norton JH, et al. Celiac disease: a study of the jejunal epithelium before and after a gluten free diet. N Engl J Med 1962; 267: 1173-9.

12 Rubin W, Ross LL, Sleisenger MH, Weiser E. An clectron microscopy study of adult celiac disease. Lab Invest 1966; 15: 1720-47.

13 Marsh MN. The small intestine: mechanisms of local immunity and gluten sensitivity. Clin Sci 1981: 61: 497503 .

14 Strober W. Gluten-sensitive enteropathy. An abnormal immunological response of the gastrointestinal tract to a dietary protein. In: Shorter RG, Kirsner JB, eds. Gastrointestinal immunity for the clinician. Orlando: Grune and Stratton, 1985: 75-112.

15 Peters JJ, Bjarnason I. Coeliac syndrome: biochemical mechanisms and the missing peptidase hypothesis revisited. Gut 1984; 25: 913-8.

16 Weiser MN, Douglas AP. An alternative mechanism for gluten toxicity in cocliac disease. Lancet 1976; i: 567-9.

17 Colyer J, Farthing MJC, Kumar PJ, Clark ML, Ohannesian AD, Waldron NM. Reappraisal of the 'lectin hypothesis' in the pathogenesis of coeliac disease. Clin Sci 1986; 71: 105-10.

18 de Franchis R, Primignani M, Cipolla M, et al. Small bowel involvement in dermatitis herpetiformis and in linear IgA bullous dermatosis. J Clin Gastroenterol 1983; 5: 429-36.

19 Primignani M, Agape D, Ronchi G, et al. Prevalence of duodenal and jejunal lesions in Dermatitis Herpetiformis. La Ricerca Clin Lab 1987; 17: 243-9.

$20 \mathrm{McNeish}$ AS, Harnus HK, Rey J, et al. The diagnosis of coeliac disease. A commentary on the current practices 
of members of the European Socicty for Pediatric Gastroenterology and Nutrition. Arch Dis Child 1979; 54: $783-6$.

21 La Mont JT. Structure and function of gastrointestinal mucus. Viewpoints Dig Dis 1985; 17: 1-4.

22 Phelps CF. Biosynthesis of mucus glycoprotein. $\mathrm{Br}$ Med Bull 1978; 34: 43-8.

$23 \mathrm{Kim}$ YS, Isaacs R, Perdomo JM. Alteration of membrane glycopeptides in Human colonic adenocarcinoma. Proc Natl Acad Sci USA 1974; 71: 4869-73.

24 Kim YS, Perdomo J, Ochoa P, et al. Regional and cellular localization of glucosyltransferase in rat small intestine. Changes in enzymes with differentiation of intestinal epithelial cells. Biochem Biophys Acta 1975; 391: $39-50$.

25 MacDonald WC, Trier JS, Everett NB. Cell prolifera- tion and migration in the stomach, duodenum and rectum of man: radiographic studies. Gastroenterology 1965; 46: 405-17.

26 Shorter RG. Moertel CG. Titus JL, et al. Cell kinetics in the jejunum and rectum of man. Am J Dig Dis 1964; 9: 760-3.

27 Trier JS, Browning TH. Epithelial-cell renewal in cultured duodenal biopsies in celiac sprue. $N$ Engl J Med 1970; 283: 1245-50.

28 Auricchio S. De Ritis G. De Vincenzi M, et al. Agglutinating activity of gliadin-derived peptides from bread wheat: implications for cocliac disease pathogenesis. Biochem Biophys Res Commun 1984; 121 : 42833.

29 Kolberg J. Sollid L. Lectin activity of gluten identified as wheat germ agglutinin. Biochem Biophys Res Commun 1985; 130: 867-72. 